\title{
Ligand-responsive Transcriptional Regulation by Members of the MarR Family of Winged Helix Proteins
}

\author{
Steven P. Wilkinson and Anne Grove* \\ Department of Biological Sciences, Louisiana State \\ University, Baton Rouge, LA 70803, USA
}

\begin{abstract}
The MarR (multiple antibiotic resistance regulator) family of prokaryotic transcriptional regulators includes proteins critical for control of virulence factor production, bacterial response to antibiotic and oxidative stresses and catabolism of environmental aromatic compounds. Recognition of the adaptive cellular responses mediated by MarR homologs, and the clinical isolation of antibioticresistant bacterial strains harboring MarR mutations, has garnered increasing medical and agricultural attention to this family. MarR proteins exist as homodimers in both free and DNA-bound states. Sequence specific DNA-binding to palindromic or pseudopalindromic sites is mediated by a conserved winged helix fold and, for numerous homologs, this association is attenuated by specific anionic lipophilic ligands. The mechanism of ligand-mediated allosteric control of DNA binding is unique amongst prokaryotic transcriptional regulators in that the DNA- and ligandbinding domains almost completely overlap in the residues involved. Until recently, our understanding of ligand-binding has been limited to a MarR-salicylate cocrystal structure, with little information on the allosteric mechanisms linking ligand-recognition and DNA-binding. However, recent biochemical and biophysical data on MarR homologs have begun to resolve the mechanisms by which these proteins mediate ligand-responsive transcriptional control.
\end{abstract}

\section{Introduction}

Proteins belonging to the MarR (multiple antibiotic resistance regulator) family of transcriptional regulators serve physiological roles as sensors of changing environments, a capacity particularly critical for pathogenic bacteria. Homologs of MarR are distributed throughout the bacterial and archaeal domains and it has been suggested that the MarR family is one of nine families of transcription factors to have evolved before the divergence of these domains over 3 billion years ago (Pérez-Rueda and Collado-Vides, 2001; Pérez-Rueda et al., 2004). Transcriptional regulation by MarR proteins is modulated by specific anionic lipophilic (usually phenolic) compounds which attenuate the ability of MarR homodimers to bind their cognate DNA sequences. The DNA binding domains of MarR proteins adopt a conserved winged helix (or winged helix-turn-helix, wHTH) fold (Fig. 1).

Since identification of the winged helix DNA-binding motif in the eukaryotic transcription factor HNF-3 $\gamma$ (Clark et al., 1993), numerous DNA-binding proteins

*For correspondence: agrove@|su.edu with a winged helix DNA recognition motif have been characterized in eukarya, prokarya, archaea and viruses. Particular interest in regards to elucidating archaeal transcriptional regulation has stemmed from analyzes of the sequenced archaeal genomes which suggest that most of the predicted HTH proteins, and most of the putative transcriptional regulators, belong to the winged helix subfamily (Aravind and Koonin, 1999; Ouhammouch and Geiduschek, 2001; Pérez-Rueda et al., 2004).

The winged helix DNA binding motif is defined topologically by secondary structure elements arranged in the following order: H1-S1-H2-H3-S2-W1-S3-W2, where " $H$ " represents $\alpha$-helix, " $S$ " represents $\beta$-strand and "W" represents a loop (Gajiwala and Burley, 2000). The sequence spanning $\alpha$-helices $\mathrm{H} 2$ through $\mathrm{H} 3$ constitutes the general $\mathrm{HTH}$ motif, with $\mathrm{H} 3$ being the DNA recognition helix. The two eponymous "wing" structures are actually formed by $\beta$-strands and loops; "wing 1 " is a $\beta$-hairpin motif, comprised of the S2-W1-S3 secondary structure elements and "wing 2" is formed by the S3-W2 elements. The three $\beta$-strands interact to form an antiparallel $\beta$ sheet, however, in some winged helix proteins $S 1$ is represented by a single, hydrophobic residue (Wilson et al., 1992; Clark et al., 1993; Martínez-Hackert and Stock, 1997; Alekshun et al., 2001). Whereas wing 1 is invariably present in winged helix proteins, some members of this family do not contain wing 2 , as observed in the crystal structures of the winged helix DNA-binding domains of E2F4, DP2, histone H5 and MarR (Brennan, 1993; Zheng et al., 1999; Alekshun et al., 2001). As observed in HNF-3 $\lambda$, the length of the turn in the winged helix motif can deviate significantly from the 3-4 residues found in canonical HTH proteins (Clark et al., 1993). Consequently, greater variation in the angle between the two helices of the $\mathrm{HTH}$ motif is observed amongst the proteins in the winged helix family than in the canonical HTH proteins. For example, the turn in DP2 is $\sim 10$ residues, whereas the turn in BirA is $\sim 3$ amino acids, allowing angles of $100^{\circ}$ and $150^{\circ}$, respectively, in these winged helix proteins (Wilson et al., 1992; Zheng et al., 1999; Gajiwala and Burley, 2000).

Structural analysis of winged helix proteins complexed with their target DNA reveals that the DNA-recognition helix (H3) almost invariably contributes most of the contacts determining sequence-specificity. However, the role of the wing(s) in contributing to DNA-binding affinity and specificity seems to vary widely, with the wings of some proteins being critical for site-specific DNA-binding by mediating numerous base-specific and sugar-phosphate backbone contacts, while in other proteins mediating few contacts. Moreover, the relative contributions from each wing (when both are present) also varies (Clark et al., 1993; Raman et al., 1997; Marsden et al., 1998; Jin and Liao, 1999; Jin et al., 1999; Zheng et al., 1999; Gajiwala et al., 2000; Zheleznova Heldwein and Brennan, 2001; van Aalten et al., 2001; Wojciak et al., 2001). 
Here we summarize physiological roles of the MarR family of winged helix proteins and emphasize biochemical and structural data on the mechanisms of ligand- and DNA-recognition (Fig. 1). Recent data that has begun to elucidate the allosteric mechanisms of transcriptional control in MarR homologs is discussed.

\section{Discovery of the mar regulon and the identification of MarR}

Identification of the MarR family of transcriptional regulators began with the recognition of a chromosomally encoded mechanism of multidrug resistance in Escherichia coli K-12 (George and Levy, 1983a; 1983b). Genetic selections identified mutants that exhibited resistance to a broad range of antibiotics including tetracycline, chloramphenicol, $\beta$-lactams, puromycin, nalidixic acid, penicillins, fluoroquinolones and organic solvents (George and Levy, 1983a; 1983b; Cohen et al., 1989; Asako et al., 1997). The mar phenotype was shown to be conferred by the marRAB operon, specifically by the expression of marA which encodes a transcriptional activator belonging to the AraC family (Cohen et al., 1993a; Gambino et al., 1993; Sulavik et al., 1994; Rhee et al., 1998). MarA is an activator of the marRAB operon and induces the expression of a number of genes responsible for the mar phenotype, including the AcrAB-TolC multidrug efflux system and micF that downregulates the synthesis of the porin OmpF (Cohen et al., 1988; 1989; Jair et al., 1995; Martin et al., 1996; Okusu et al., 1996). In vivo upregulation of marRAB expression and the mar phenotype was shown to be inducible by a range of antibiotics and anionic lipophilic compounds including 2,4-dinitrophenol, menadione, plumbagin and salicylic acid (Cohen et al., 1993b; Seoane and Levy, 1995).

The product of the first gene of this locus, MarR (144 amino acids), is a transcriptional repressor of the marRAB operon, binding to two separate 21 bp sites in the marRAB promoter/operator region (marO) with an apparent $\mathrm{K}_{\mathrm{d}}$ of $\sim 1 \mathrm{nM}$ (Cohen et al., 1993b; Ariza et al., 1994; Martin and Rosner, 1995). DNase I footprinting indicated that MarR binding site I overlaps the predicted -35 and -10 promoter elements and site II overlaps the putative ribosome binding site and ends immediately before the first codon of marR. The size of each footprint and the fact that each binding site is palindromic with 5 bp half-sites separated by 2 bp is consistent with MarR binding as a homodimer at each site, a conclusion supported by size-exclusion chromatography evidence for uncomplexed MarR existing as a dimer, or higher order oligomers, in solution. Interestingly, a number of phenolic compounds that have been shown to increase marRAB expression in vivo also antagonize MarR-marO complex formation in vitro, including 2,4-dinitrophenol, menadione, plumbagin and salicylic acid; MarR binds salicylic acid with an apparent $\mathrm{K}_{\mathrm{d}}$ of $0.5 \mathrm{mM}$ (Martin and Rosner, 1995; Alekshun and Levy, 1999). These results in toto revealed a system of intrinsic multidrug resistance in $E$. coli that is under the control of a novel transcriptional repressor, MarR, that responds to cytoplasmic phenolic compounds. Clinical isolates of quinolone-resistant strains of $E$. coli have been determined to have MarR mutations, indicating the medical importance of this protein (Maneewannakul and Levy, 1996). Functional marRAB operons have since been identified in Salmonella typhimurium, Enterobacter aerogenes and other enteric bacteria (Sulavik et al., 1997; Chollet et al., 2002).

\section{Transcriptional regulation by the MarR family}

Bacteria and archaea have adapted the MarR protein fold to regulate genes critical for response to changing environments. The majority of characterized MarR proteins are transcriptional repressors but several activators have been identified (SlyA is suggested to do both). The gene encoding each MarR homolog is generally part of a gene cluster containing the gene(s) under its regulation (with a couple of notable exceptions) and in some cases, the MarR homolog is encoded in its regulated operon. A large proportion of the characterized family members are adjacent to the divergently transcribed gene(s) they regulate such that the MarR homolog binding site(s) reside in the intergenic region containing the associated, divergent promoters. More than half of the characterized MarR homologs have been shown to be autoregulatory. The locations of the MarR binding sites often overlap the -35 and/or -10 promoter elements of their target genes, suggesting that repression is achieved by steric inhibition of RNA polymerase binding to the promoter. However, the homolog HpaR from $E$. coli likely represses transcription by blocking promoter escape by RNA polymerase, while SlyA from Salmonella typhimurium has been suggested to prevent open complex formation and the binding sites of other homologs suggest that they impede transcriptional elongation (Stapleton et al., 2002; Galán et al., 2003). Cooperative binding to closely spaced recognition sequences has been demonstrated for OhrR from Bacillus subtilis and may occur for other MarR homologs, as well (Evans et al., 2001; Fuangthong and Helmann, 2002; Stapleton et al., 2002). The physiological roles of MarR proteins can be classified into three general categories with some proteins serving multiple regulatory roles: 1) regulation of response to environmental stress, 2 ) regulation of virulence factors, and 3) regulation of aromatic catabolic pathways.

MarR regulators of stress response and virulence factors In addition to MarR, several homologs control transcription of operons involved in antibiotic stress response. The gene encoding one of the more characterized homologs, MexR from Pseudomonas aeruginosa, is adjacent to the oppositely oriented mexAB-oprM operon that encodes a non-ATPase, multisubstrate efflux pump that contributes to this organism's intrinsic multidrug resistance; MexR represses its own transcription and that of the mexABoprM operon (Poole et al., 1996; Srikumar et al., 2000). A $P$. aeruginosa strain harboring a mexR mutation was shown to have enhanced resistance to antibiotics (Poole et al., 1996). EmrR from E. coli was first demonstrated to be a repressor of microcin $B$ and $C$ production and later shown to be the encoded by the first gene of the emrRAB operon which encodes a multidrug resistance pump (del Castillo et al., 1990; Lomovskaya et al., 1995). EmrR represses the emrRAB locus and this repression is relieved by certain antibiotics and protonophores that are the targets of the EmrRAB pump. In addition, the MarR 


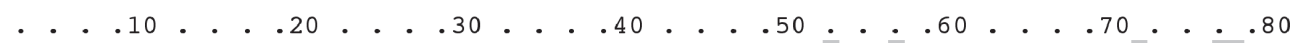

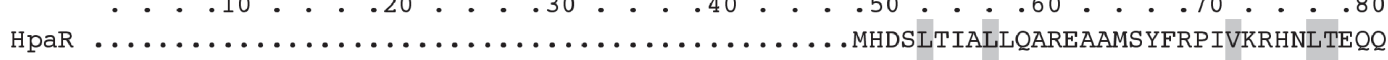

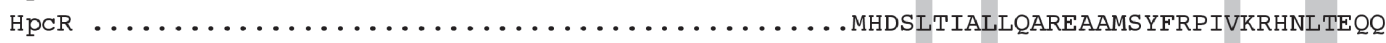

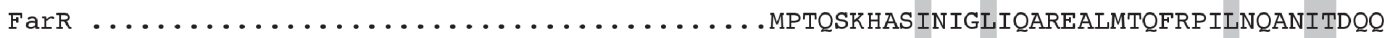

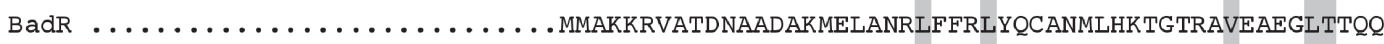

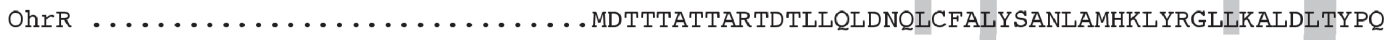

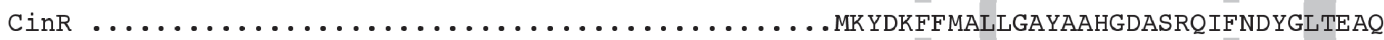

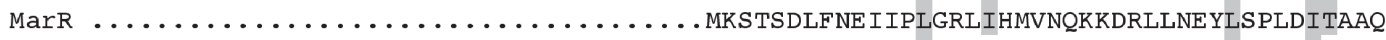
EmrR $\ldots \ldots \ldots \ldots \ldots \ldots \ldots$ MDSSFTPIEQMLKFRASRHEDFPYQEILITRLCMHMQSKLLENRNKMLKAQGINETL PecS $\ldots \ldots \ldots \ldots \ldots \ldots \ldots \ldots$ MARYLEVSDIVQQWRNERPDLDVEPMLVIGTLSRVSLLIDRALDKVFSKYKLSARE HUCR $\ldots \ldots \ldots$ MSARMDNDTAALLERIRSDWARLNHGQGPDSDGLTPSAGPMLTLLLLERLHAALGREIERTYAASGLNAAG

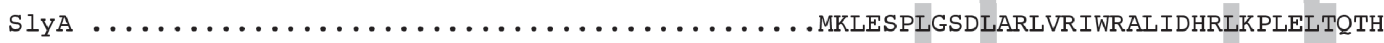
HCaR $\ldots \ldots \ldots \ldots \ldots \ldots \ldots \ldots \ldots \ldots \ldots \ldots \ldots \ldots \ldots \ldots$ MLSSSVDRKREEPRLS YMIARVDRI ISKYLTEHLSALEISLPQ

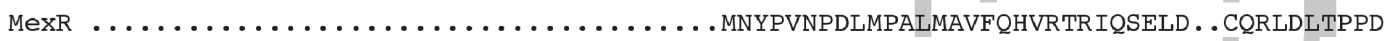
CbaR $\ldots \ldots \ldots \ldots \ldots \ldots \ldots \ldots \ldots \ldots \ldots \ldots \ldots \ldots$ MLARDRKSRVTLNLDTYTPAFFTAIANKLASGASKDYLKNFGIGIET

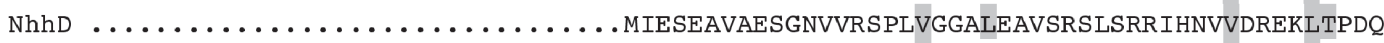
HPr $\quad \ldots \ldots \ldots \ldots \ldots \ldots \ldots \ldots \ldots \ldots \ldots \ldots \ldots \ldots \ldots \ldots \ldots \ldots \ldots$ MNREPYDVKEALVF TQKMAQLSKALWKS IEKDWQQWLKPYDLNINE EXPG MERGMNHRILYPFADFGDTVAILPANETQRKGLDTPVDDRDGDDSLVTYFELARVMERASRRFSGLLRAELTKLGVEDIG $\alpha 12 \frac{0}{\alpha 2}$

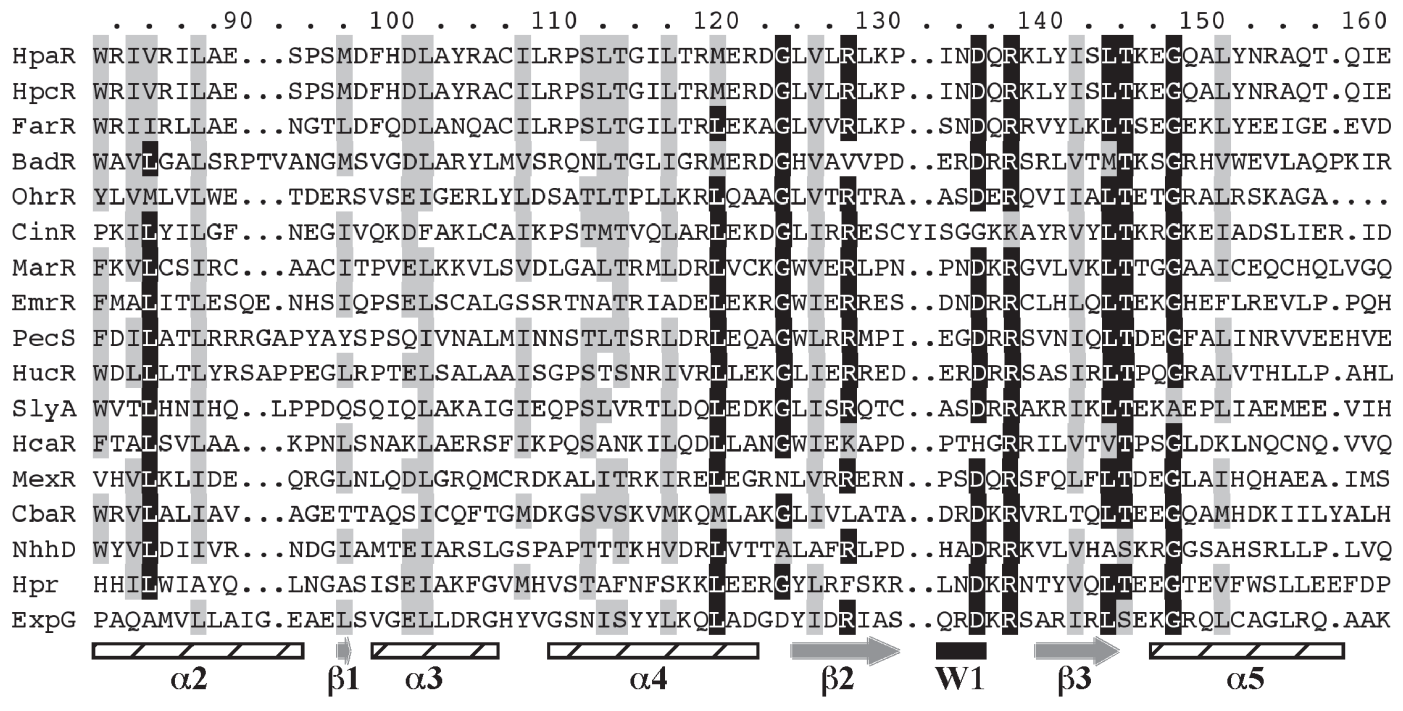
..170.. 180 . . 190 . . 200 . . 210 . 2200

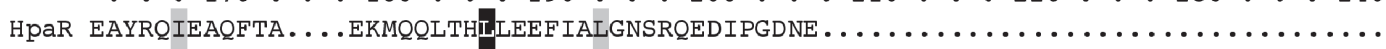
HPCR EAYRQIEAQFTA. . . EKMQQLTHLLEEFIALGNSRQEDIPGDNE $\ldots \ldots \ldots \ldots \ldots \ldots \ldots \ldots \ldots \ldots \ldots \ldots$

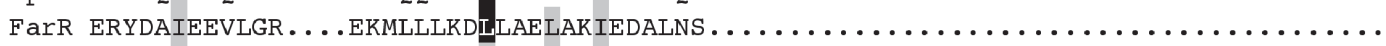
BadR AYYGEVLGDFSINDVTHTLHYLLKILDNMKRLDDGAAGETAATDLE. $\ldots \ldots \ldots \ldots \ldots \ldots \ldots \ldots \ldots \ldots \ldots$

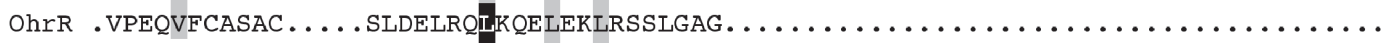

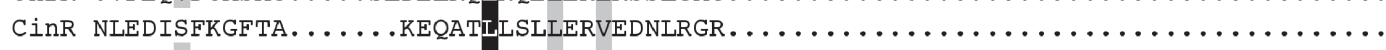

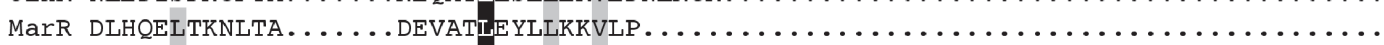
EMrR NCLHOLWSALSTTEKDQLEQITRKLLSRLDQMEQDGVVLEAMS $\ldots \ldots \ldots \ldots \ldots \ldots \ldots \ldots \ldots \ldots \ldots \ldots$

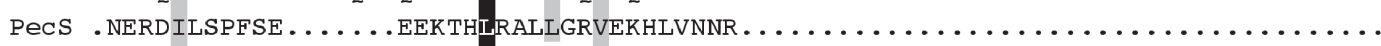
HuCR ATTQRVLAPLSA. . . . QEQRTLEELAGRMLAGLEQGV $\ldots \ldots \ldots \ldots \ldots \ldots \ldots \ldots \ldots \ldots \ldots \ldots$ SIYA KTRGEILAGISS . . . . EEIELLIKLIAKLEHNIMELHSHD $\ldots \ldots \ldots \ldots \ldots \ldots \ldots \ldots \ldots \ldots \ldots \ldots$

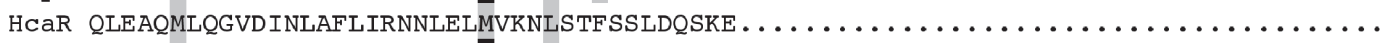

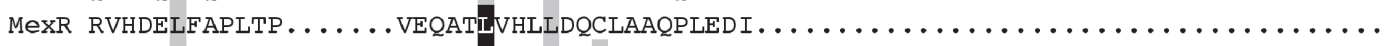
CbaR .RENSLLSVLTA $\ldots \ldots$. SERETLVRLLQRLKENINRVDIDSSLYVKAHWHRESPQE $\ldots \ldots \ldots \ldots \ldots \ldots \ldots$ NhhD QVEDEFMDELAIP. . . . DRQVLRTVLETWFA. . . . . . . . . . . . . . . . . . . . . HPr TRNAVFKGSQPLYHLFGKFPEVAEMMCMIRHIYGDDF MEIFE TSLTNIDNDFESVNGKLKKKAKDSAADE PAEELE PVNS EXPG GYERALSHGDQD $\ldots \ldots \ldots$ RRNLETAFQTLHRLELVWGNARYGI $\ldots \ldots \ldots \ldots \ldots \ldots \ldots \ldots \ldots \ldots$ $\frac{\alpha 5}{\alpha 6}$

Fig. 1 Multiple sequence alignment of members of the MarR family. The alignment was generated using ClustalX. Light and dark shading indicates $\geq 70 \%$ similarity or identity at that position, respectively. Residue numbering is according to the entire alignment, and not from any one protein. Secondary structure elements indicated below the alignment show conservation of the wHTH motif and are based on the MarR crystal structure (1JGS), with $\alpha$-helices represented as hatched boxes, $\beta$-strands as arrows and the wing as a filled box (Alekshun et al., 2001). The HTH domain corresponds to helices $\alpha 3$ and $\alpha 4$, with $\alpha 4$ constituting the recognition helix. Ligand-binding sites SAL-A and SAL-B flank the recognition helix, with highly conserved residues from both helices of the HTH motif and the wing forming the SAL-A site and most contacts to the ligand in site SAL-B mediated by residues in the recognition helix. The $\beta$-hairpin "wing" motif is formed by the $\beta 2, W 1, \beta 3$ structural elements. Helices $\alpha 1, \alpha 5$ and $\alpha 6$ form the dimerization domain. 
ligands salicylate and 2,4-dinitrophenol also induced expression of this operon (Lomovskaya et al., 1995).

A MarR homolog has been characterized from Neisseria gonorrhoeae that likely mediates the resistance of this organism to antimicrobial hydrophobic agents. FarR represses its own transcription and that of the distally located farAB operon of $N$. gonorrhoeae, which encodes an efflux pump that exports host-derived antimicrobial agents such as long-chain fatty acids (Lee et al., 2003).

The gene encoding OhrR from Xanthomonas campestris pv. phaseoli is co-transcribed with the adjacent gene, ohr, which is involved in protection against organic peroxides. Transcription of this unit is antagonized by OhrR and this repression is relieved by certain organic peroxides (Sukchawalit et al., 2001; Mongkolsuk et al., 2002). Numerous bacteria maintain this genetic organization of ohrR and ohr, but in $B$. subtilis these genes are adjacent and oriented in the opposite direction. $B$. subtilis OhrR represses transcription of ohr and is responsive to organic peroxides but does not appear to be autoregulatory (Fuangthong et al., 2001; Fuangthong and Helmann, 2002).

SlyA from S. typhimurium likely serves as both a transcriptional repressor and activator, regulating its own expression and that of at least 23 genes including some involved in oxidative stress response and resistance to certain antimicrobial peptides (Spory et al., 2002; Stapleton et al., 2002; Shi et al., 2004).

As the MarR homologs described above are important for the organism surviving host-derived antimicrobial agents, all could be classified as regulators of virulence factors as well. For example, SlyA also regulates hemolysin and flagella production, both of which are critical for $S$. typhimurium infection (Stapleton et al., 2002; Wyborn et al., 2004). Similarly, PecS from the plant pathogen Erwinia chrysanthemi represses the transcription of a cluster of genes involved in the synthesis of the pigment indigoidine which is likely involved in scavenging reactive oxygen species (Reverchon, et al., 2002). PecS also represses the transcription of pectinase and cellulase enzymes and genes involved in flagellum development, virulence factors required for this organism to infect plant cells (Praillet et al., 1996; Rouanet et al., 1999; 2004). The MarR homolog ExpG from the nitrogenfixing soil bacterium Sinorhizobium meliloti has been shown to activate transcription of three exp operons that are involved in the production of galactoglucan, an exopolysaccharide required for this organism to infect plant roots for nodule formation (Becker et al., 1997; Rüberg et al., 1999; Bartels et al., 2003).

\section{MarR regulators of aromatic catabolism}

A number of characterized MarR homologs regulate metabolic pathways of aromatic compounds. Most of these proteins participate in environmental surveillance of the substrate compound, with their regulatory capacity being mediated by direct association with the phenolic molecule. The MarR homolog CbaR from Comamonas testosteroni BR60 is not autoregulatory, but the location of its binding site indicates that it represses the transcription of the adjacent, oppositely oriented $c b a A B C$ operon which encodes enzymes involved in the oxidation of 3-chlorobenzoate (Providenti and Wyndham, 2001). Transcriptional repression is relieved by $\mathrm{CbaR}$ binding to 3-chlorobenzoate or the downstream catabolic product protocatechuate. Similarly, HpaR from E. coli represses transcription of the hpa-meta operon which encodes genes for the catabolism of 4-hydroxyphenylacetic acid and this repression is relieved by 4-hydroxyphenylacetic acid and structurally similar compounds (Galán et al., 2003). HucR from Deinococcus radiodurans is a transcriptional autorepressor and repressor of an adjacent uricase enzyme which is involved in the aerobic purine degradation pathway (Wilkinson and Grove, 2004; 2005). The substrate of uricase, uric acid, is an efficient antagonist of HucR-DNA association and uric acid upregulates hucR and uricase transcription (Wilkinson and Grove, 2004). As uric acid is a scavenger of reactive oxygen species, HucR is likely to be involved in the oxidative stress response of this organism.

In contrast to the majority of MarR proteins, ligandbinding appears to enhance the DNA-binding affinity of some homologs involved in pathways of aromatic catabolism. BadR from Rhodopseudomonas palustris induces transcription of the badDEFG operon which encodes benzoyl-CoA reductase, an enzyme involved in the anaerobic catabolism of benzoate, and this induction is enhanced by benzoate or 4-hydroxybenzoate (Egland and Harwood, 1999). Whereas 3-chlorobenzoate is an antagonist of DNA-binding by the CbaR repressor, 3hydroxybenzoate and 3-carboxybenzoate likely increase CbaR DNA-binding affinity (Providenti and Wyndham, 2001).

\section{Structural analysis of MarR homologs}

Structural data are only available for a few MarR homologs, however, several characteristic features of this family can be discerned. First, MarR proteins exist as homodimers in solution and the subunit association is mediated primarily by hydrophobic contacts between intercalating $\mathrm{N}$ - and $\mathrm{C}$-terminal $\alpha$-helices. The subunits are related by a twofold symmetry. Second, the dimerization domain of each subunit is connected via long $\alpha$-helices to a globular DNAbinding domain that adopts a winged helix fold. The DNAbinding domains in the dimer are separated by a channel and make few direct contacts.

The $2.3 \AA$ co-crystal structure of a MarR-salicylate complex reveals the protein to exist as a dimer with a pyramidal shape and overall dimensions of $50 \times 55 \times$ $45 \AA$ (Fig. 2a) (Alekshun et al., 2001). Each monomer consists of $6 \alpha$-helices and two $\beta$-strands. The $\mathrm{N}$-terminal $\alpha$-helix 1 and the $\mathrm{C}$-terminal helices 5 and 6 interdigitate with the corresponding regions of the other subunit to form a dimerization domain with a buried surface area of $3570 \AA^{2}$. Stabilization of the homodimer is predominantly mediated by hydrophobic contacts involving 10 residues from each subunit. Several inter-subunit hydrogen bonds in this domain contribute to dimer stability: the $\mathrm{N} \zeta$ of a lysine in helix $1 \mathrm{H}$-bonds with the main chain carbonyl of the $\mathrm{C}$-terminal residue and the $\mathrm{N} \zeta$ of a lysine in helix 6 $\mathrm{H}$-bonds with the main chain carbonyl in the $\mathrm{N}$-terminal coil region.

Helices 1 and 5 of each subunit connect the dimerization domain to a globular DNA-binding domain 
(a)
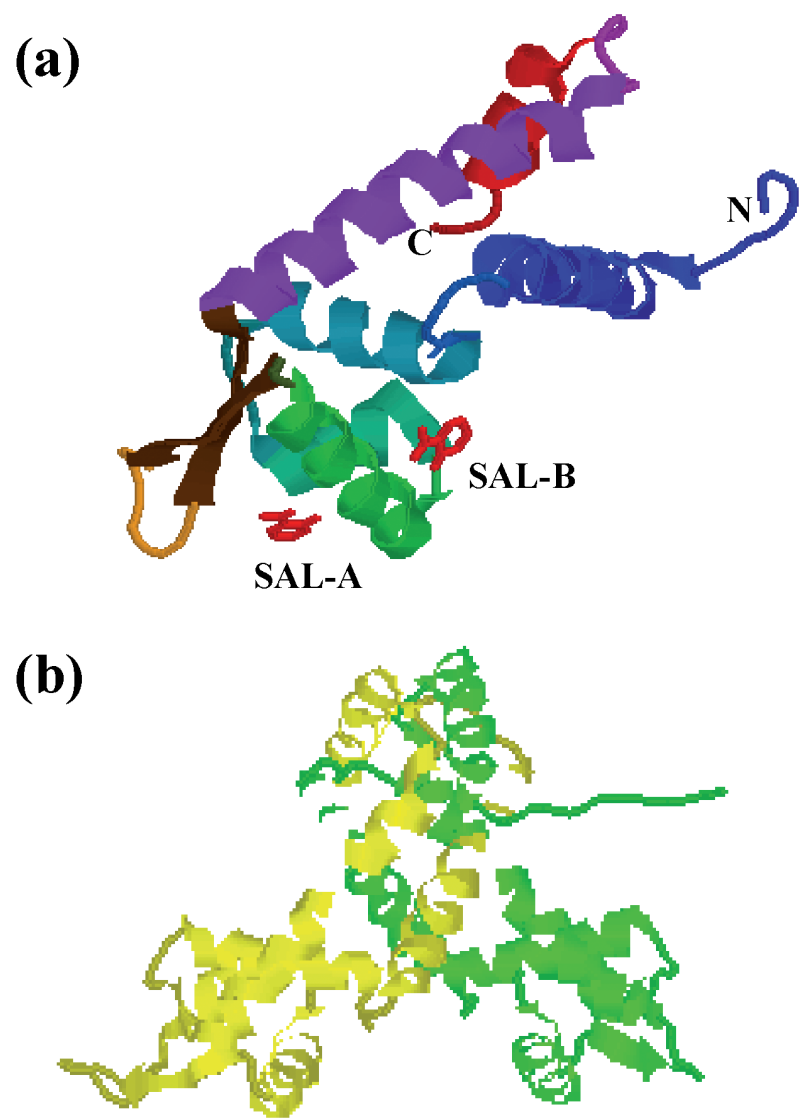

(c)
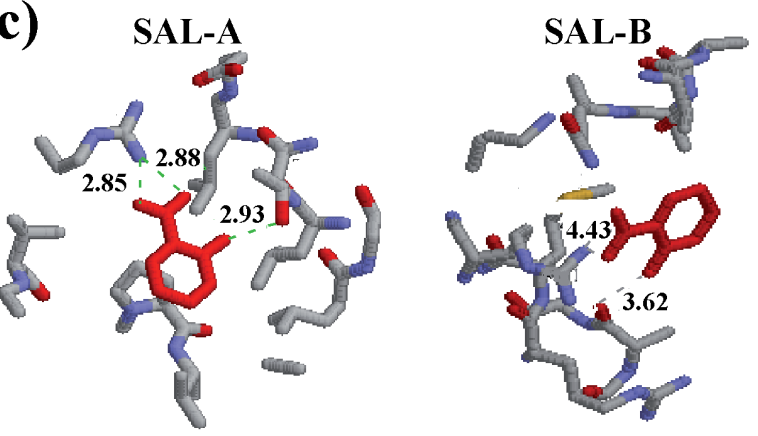

Fig. 2 Structures of MarR and MexR. A) Ribbon representation of the MarR monomer (1JGS) with the N- and C- termini labeled. Salicylate molecules (red) in sites SAL-A and SAL-B are shown flanking the putative DNA recognition helix (green). The wing is composed of anti-parallel $\beta$-strands (brown) and the intervening loop (yellow) (Alekshun et al., 2001). B) MexR in its "open" predicted DNA binding conformation (1LNW). The individual subunits of dimer CD are colored yellow and green, with the winged helix motifs at the bottom of the structure (Lim et al., 2002). C) MarR salicylate binding sites SAL-A and SAL-B. Salicylates are colored red. Oxygen, nitrogen and sulfur atoms from MarR side-chains are colored red, blue and yellow, respectively. Predicted hydrogen bonds are represented as dashes with approximate distances indicated (in $\AA$ ).

such that the two DNA-binding "lobes" of the dimer are juxtaposed and related by two-fold rotational symmetry. The topological arrangement of secondary structure elements in the DNA-binding domain (H1-S1-H2-H3-S2W1-S3) indicates that MarR binds via a winged helix motif. Each DNA-binding domain is stabilized by hydrophobic interactions involving 14 residues from each of the secondary structural elements. The residues spanning helices 3 and 4 (corresponding to $\mathrm{H} 2-\mathrm{H} 3$ above) constitute the HTH motif (Fig. 1). The $\beta$-hairpin (S2-W1-S3) following the HTH motif forms the eponymous "wing" structure. The $\beta$-strands (S1, S2, S3) in each MarR subunit form an antiparallel $\beta$-sheet with $\mathrm{S} 1$ being comprised of a single isoleucine residue, similar to the structures of $\mathrm{OmpR}$ and BirA (Wilson et al., 1992; Martínez-Hackert and Stock, 1997). The wing extending from S3 in some winged helix proteins is absent from the DNA-binding domain of MarR, resembling the structures of E2F4, DP2, and histone $\mathrm{H} 5$ (Brennan, 1993; Zheng et al., 1999). The surface potential of each DNA-binding domain is highly electropositive and a $6 \AA$ wide cleft separates the lobes from each subunit. In this salicylate-bound structure, the DNA-binding lobes of MarR interact through two salt bridges: D67 from the turn of the HTH contacts R73 in the putative recognition helix of the other subunit (and the reciprocal interaction).

The crystal structure of $P$. aeruginosa MexR in the absence of effector was solved at $2.1 \AA$ and revealed an overall pyramidal structure very similar to MarR (Fig. 2b) (Lim et al, 2002). Four copies of the MexR dimer were present in the crystallographic asymmetric unit, providing several conformational views. The 147 amino acid MexR monomer is comprised of $6 \alpha$-helices and $3 \beta$-strands. The $\mathrm{N}$ - and $\mathrm{C}$-terminal regions encompassing $\alpha$-helices 1,5 and 6 from each subunit intertwine with the reciprocal regions in the other subunit to create a dimerization interface with a total buried surface area of 4360-4930 $\AA^{2}$. Stabilization of the dimer is provided almost entirely by hydrophobic contacts. Helices 1 and 5 of each subunit connect the dimerization domain to a compact, globular DNA-binding domain (residues 36-97). The DNA-binding domain adopts a winged helix fold with the sequence spanning helices 3 and 4 forming the HTH. $\beta$-strands 2 and 3 and the intervening sequence form the wing. As for MarR, MexR lacks a wing 2 structure. The two salt bridges that connect the DNA-binding lobes of the MarR dimer are absent in the MexR structure.

The structure of a SlyA homolog from the pathogen Enterococcus fecalis was solved at $1.6 \AA$, revealing a dimer with an overall structure very similar to MarR and MexR despite considerable sequence difference (Wu et al., 2003). This 150 amino acid protein is comprised of seven $\alpha$-helices and three $\beta$-strands, with helices 1,6 , and 7 from each subunit interdigitating with their counterparts in the other subunit to form a dimerization domain stabilized primarily by hydrophobic interactions. Hydrophobic interactions also stabilize a globular DNAbinding domain that adopts a winged helix fold with the putative DNA-recognition helix (helix 5 ) flanked by a wing ( $\beta$-strands 2,3 , and intervening region). The DNA-binding domains in the dimer are separated by a channel and, like MexR, make no direct contacts.

Sequence alignment of characterized MarR family members reveals conservation of residues throughout the entire protein (Fig. 1). The conservation of hydrophobic amino acids suggests their importance in adopting a stable fold or mediating intersubunit contacts in the homodimeric assembly. The residues comprising the C- 
terminal portion of the winged helix motif are especially conserved, particularly in the wing itself, with eight of the ten highly conserved amino acids residing in this region.

\section{DNA-binding by MarR proteins}

The structural, biochemical and genetic data available to date is insufficient to explain the DNA-binding mechanism of MarR. However, a cumulative view of DNA-binding properties of MarR homologs presents some characteristic features. The cognate DNA-binding sites of MarR proteins are invariably comprised of (pseudo)palindromic sequences, suggesting that members of this family bind DNA as dimers. However, the lengths of the inverted repeats and the spacing between half-sites are variable (Table 1). Consequently, the centers of the half-sites are expected to vary in their relative positions on the DNA double-helix, ranging from the same face to opposite faces of the DNA.

The structure of salicylate-bound MarR does not allow modeling onto B-DNA with the known MarR binding sequences, consistent with evidence that salicylate is a negative effector of MarR-marO complex formation. Nevertheless, the combined data from the MarRsalicylate co-crystal structure, footprinting experiments and mutational studies suggest possible modes of DNArecognition. The identification of $5 \mathrm{bp}$ inverted repeats separated by 2 bp within each 21 bp MarR binding site would place the half-site sequences on opposite faces of the DNA double helix (Martin and Rosner, 1995). As other MarR homologs bind their cognate DNA sites as homodimers to palindromic sequences, it is reasonable to suspect that MarR does so as well (Wilkinson and Grove, $2004 ; 2005)$. The DNA-binding lobes of the salicylatebound MarR structure would have to undergo significant conformational changes to accommodate binding to DNA half-sites on opposite faces of the double helix. Such conformational shifts of the globular DNA-binding domains would require flexibility in the $\alpha$-helices that connect the lobes to the dimerization domain. That MarR possesses such intrinsic flexibility is supported by the crystal structure, which indicates poorly ordered loop regions that might allow conformational shifts in the $\alpha$-helices that form the dimerization domain (Alekshun et al., 2001). Also, the van der Waals interactions that stabilize the dimer do not require specific geometries of the residues involved, suggesting that flexibility would be allowed at the dimer interface. In addition, in vivo selections of MarR mutants with altered DNA-binding activity indicated that residues in the $\mathrm{N}$ - and $\mathrm{C}$-terminal regions (in addition to the winged helix motif) are important in defining DNA-binding affinity (Alekshun and Levy, 1999b; Alekshun et al., 2000). Furthermore, MarR crystals grown in the absence of ligand were determined to be highly disordered, consistent with MarR being intrinsically flexible (Alekshun et al., 2001). Protein-induced conformational changes in the DNAbinding site could also accommodate binding of a MarR dimer. For example, overwinding or underwinding of the DNA duplex to change the helical twist would serve to

\begin{tabular}{|c|c|c|c|c|c|}
\hline Protein & Organism & Footprint (bp) ${ }^{a}$ & $\mathrm{~K}_{\mathrm{d}}(\mathrm{nM})$ & $(\text { bp in } 1 / 2 \text { sites })^{f}$ & Ref. \\
\hline MarR & Escherichia coli & 21 & 1 & $5(2)$ & $\begin{array}{l}\text { Martin and Rosner, } \\
1995\end{array}$ \\
\hline EmrR & Escherichia coli & 42 & -- & $9(3)$ & Xiong et al., 2000 \\
\hline MexR & $\begin{array}{l}\text { Pseudomonas aeru- } \\
\text { ginosa }\end{array}$ & 28 & -- & $5(5)$ & Evans et al., 2001 \\
\hline CbaR & $\begin{array}{l}\text { Comamonas testos- } \\
\text { teroni }\end{array}$ & 22 & -- & $4(6$ or 9$)$ & $\begin{array}{l}\text { Providenti and Wynd- } \\
\text { ham, } 2001\end{array}$ \\
\hline CinR & Butyrivibrio fibrisolvens & -- & -- & $8(0)$ & $\begin{array}{l}\text { Dalrymple and } \\
\text { Swadling, } 1997\end{array}$ \\
\hline HpaR & Escherichia coli & 27 & -- & $9(4)$ & Galán et al., 2003 \\
\hline ExpG & Sinorhizobium meliloti & $21^{b}$ & $0.58-1.3$ & $6(3)$ & $\begin{array}{l}\text { Bartels et al., 2003; } \\
\text { Baumgarth et al., } 2005\end{array}$ \\
\hline PecS & Erwinia chrysanthemi & 45 & $4-200$ & $5(3)$ & $\begin{array}{l}\text { Praillet et al., 1997; } \\
\text { Rouanet et al., 1999; } \\
\text { Reverchon et al., } \\
\text { 2002; Rouanet et al., } \\
2004\end{array}$ \\
\hline SlyA & $\begin{array}{l}\text { Salmonella typhimuri- } \\
\text { um }\end{array}$ & $25^{c}$ & -- & $5(2)$ & Stapleton et al., 2002 \\
\hline OhrR & $\begin{array}{l}\text { Xanthomonas camp- } \\
\text { estris }\end{array}$ & 44 & -- & $8(17)$ & $\begin{array}{l}\text { Mongkolsuk et al., } \\
2002\end{array}$ \\
\hline OhrR & Bacillus subtilis & $42^{\mathrm{d}}$ & $5^{d}$ & $7(7)$ & $\begin{array}{l}\text { Fuangthong et al., } \\
\text { 2001; Fuangthong and } \\
\text { Helmann, } 2002\end{array}$ \\
\hline HucR & $\begin{array}{l}\text { Deinococcus radio- } \\
\text { durans }\end{array}$ & $21^{\mathrm{e}}$ & 0.29 & $8(2)$ & $\begin{array}{l}\text { Wilkinson and Grove, } \\
2004\end{array}$ \\
\hline
\end{tabular}


position the major groove of each half-site in an orientation that would require a less drastic conformational change in the MarR dimer. Biophysical experiments to ascertain the conformational flexibility of MarR and its cognate DNA-binding sequence would be crucial in testing these possibilities.

The crystal structure of MexR in the absence of a ligand (Fig. 2b) revealed a dimer in a conformation that could be docked to a linear B-form representation of its known DNA-binding sequence with a reasonably good fit (Lim et al, 2002). The sequence-specific MexR binding site contains $5 \mathrm{bp}$ half-sites separated by $5 \mathrm{bp}$, so that the center of each half-site would likely be positioned on the same face of the DNA duplex (Evans et al., 2001). The MexR dimer (denoted "CD") modeled onto the DNA-binding site was determined to be in an "open" conformation, such that the globular DNA-binding lobes were separated by a distance optimal for the insertion of the recognition helices into consecutive major grooves and the wings were positioned to mediate contacts with the sugar-phosphate backbone and minor groove (Lim et al., 2002). The MexR dimer CD structure reveals the centers of the two recognition helices to be separated by $29.2 \AA$, close to the $34 \AA$ distance that separates the center of each half-site in linear B-form DNA. This "open" conformation is likely maintained by electrostatic repulsion between positively charged residues lining the crevice between the DNA-binding domains. The model suggests that bending of the DNA duplex, or an increase in the helical twist, might occur upon MexR binding to accommodate a tighter fit. Additionally, the DNA-binding lobes of the MexR dimer might undergo conformational shifts, a possibility suggested by the intrinsic flexibility of the MexR dimer (see below).

Recent data for ExpG and HucR suggests that the DNA-binding mechanisms in this family indeed involve conformational flexibility of both the protein dimer and DNA. Analysis of ExpG-DNA binding using atomic force microscopy (AFM) revealed that the DNA curvature at the ExpG binding site changes upon complex dissociation, suggesting that ExpG induces DNA bending upon complex formation (Baumgarth et al., 2005). Electrophoretic mobility shift assays (EMSA) and AFM experiments demonstrated that ExpG binding sites require a palindromic sequence comprised of 6 bp halfsites separated by 3 bp (Bartels et al., 2003; Baumgarth et al., 2005). Binding kinetics for ExpG at 3 different sites indicated that the ExpG dimer binds with a very high onrate $\left(1.0-5.0 \times 10^{5} \mathrm{M}^{-1} \mathrm{~s}^{-1}\right)$ and dissociates with a very low off-rate $\left(4.3-1.3 \times 10^{-4} \mathrm{~s}^{-1}\right)$ indicating dissociation constants of $0.58-1.3 \mathrm{nM}$. Interestingly, the DNAbinding affinity of ExpG is enhanced by the presence of short conserved sequences ("boxes 1 and 2") located on either side of the palindrome. The distance of these boxes from the conserved $21 \mathrm{bp}$ sequence containing the palindrome is $5-30 \mathrm{bp}$. Dynamic force spectroscopy was used to calculate the natural thermal off-rates for the binding kinetics between ExpG and a wild-type binding site, a binding-site mutated in Box 1 and a binding site mutated in Box 2. The off-rate was increased $\sim 10$-fold by a mutation in Box 1 and $\sim 100$-fold by a mutation in
Box 2. Sites analogous to boxes 1 and 2 have not been described for any other MarR family member.

HucR-association with its cognate binding sequence also involves conformational changes in the DNA doublehelix, as first suggested by sites of DNase I hypersensitivity flanking the HucR footprint (Wilkinson and Grove, 2004). Circular dichroism spectroscopy revealed a significant alteration to the secondary structure of the DNA upon complex formation with HucR consistent with a reduction in the helical twist of the DNA duplex (Wilkinson and Grove, 2005). Equilibrium analytical ultracentrifugation indicated that HucR predominantly exists as a dimer in solution. EMSA and measurements of intrinsic fluorescence confirmed that HucR binds its pseudopalindromic DNA site as a homodimer and analysis of HucR mutants provided evidence that the wing mediates contacts with DNA. Intrinsic fluorescence measurements suggested DNA-induced global conformational changes in the HucR dimer extending to the globular protein interior of the protein and to the dimerization domain. This inherent flexibility in HucR to accommodate DNA-binding is consistent with structural data on MarR, MexR and SlyA. Taken together, the structural and biochemical evidence for MarR homologs suggests protein conformational flexibility to be a general requirement for accommodating site-specific DNA-binding, with some proteins deforming the DNA to stabilize the interaction.

\section{Ligand recognition by MarR proteins}

A defining characteristic of numerous members of the MarR family is the capacity to bind diverse anionic lipophilic (usually phenolic) effector molecules (Table 2). Structural data for MarR and MexR and recent biochemical data on HucR have provided insights into a novel mechanism of ligand-binding in this family in which DNA- and effectorbinding domains overlap. The MarR-salicylate co-crystal structure revealed two ligand binding sites per subunit, labeled SAL-A and SAL-B (Fig. 2) (Alekshun et al., 2001). Notably, the bound salicylates flank the proposed DNArecognition helix. Ligand binding site SAL-A is packed in the interior of the globular DNA-binding domain, and is formed by residues from both helices of the HTH motif and from the wing. The side chain hydroxyl of T72 from the recognition helix forms an $\mathrm{H}$-bond with the salicylate hydroxyl group, the guanidinium group of R86 H-bonds with the salicylate carboxylate and the aliphatic pyrrolidone ring of P57 is positioned within $3.5 \AA$ of the hydrophobic ring of salicylate. SAL-B is exposed to the solvent and most contacts with salicylate are mediated by residues from the recognition helix. The backbone carbonyl of A70 $\mathrm{H}$-bonds to the salicylate hydroxyl, the guanidinium group of $\mathrm{R} 77 \mathrm{H}$-bonds with the salicylate carboxylate and the hydrophobic ring of salicylate is within $3.5 \AA$ of the hydrophobic side chain of M74. Q42 from helix 2 may also $\mathrm{H}$-bond with the salicylate carboxylate.

The $\mathrm{H}$-bond forming residues in site SAL-A are strictly conserved in MexR while the MarR proline mediating hydrophobic contact with the salicylate ring is replaced with a leucine in MexR. Site SAL-B, however, is not conserved in MexR. The natural ligands of MexR are unknown and the structure was determined in the 


\begin{tabular}{|c|c|c|c|c|}
\hline Protein & Organism & Ligands & $\mathrm{K}_{\mathrm{d}}$ (apparent) & Ref. \\
\hline EmrR & Escherichia coli & $\begin{array}{l}\text { Nalidixic acid, salicylate, caronyl cya- } \\
\text { nide m-chlorophenylhydrazone, } \\
\text { 2,4-dinitrophenol, ethidium bromide }\end{array}$ & $1.3-11.1 \mu \mathrm{M}$ & $\begin{array}{l}\text { Lomovskaya et al., } \\
1995 \\
\text { Brooun et al., } 1999 \\
\text { Xiong, et al., } 2000\end{array}$ \\
\hline BadR & Rhodopseudomonas palustris & Benzoate, 4-hydroxybenzoate & -- & $\begin{array}{l}\text { Egland and Har- } \\
\text { wood, } 1999\end{array}$ \\
\hline CbaR & Comamonas testosteroni & 3-chlorobenzoate, protocatechuate & -- & $\begin{array}{l}\text { Providenti and } \\
\text { Wyndham, } 2001\end{array}$ \\
\hline CinR & Butyrivibrio fibrisolvens & Cinnamic acid sugar esters & -- & $\begin{array}{l}\text { Dalrymple and } \\
\text { Swadling, } 1997\end{array}$ \\
\hline $\mathrm{HcaR}$ & Acinetobacter sp. strain ADP1 & hydroxycinnamoyl-CoA thioesters & -- & $\begin{array}{l}\text { Parke and Orn- } \\
\text { ston, } 2003\end{array}$ \\
\hline HpaR & Escherichia coli & $\begin{array}{l}\text { 4-hydroxyphenylacetic acid, 3-hydroxy- } \\
\text { phenylacetic acid, 3,4-hydroxyphenyl- } \\
\text { acetic acid }\end{array}$ & -- & Galán et al., 2003 \\
\hline MarR & Escherichia coli & $\begin{array}{l}\text { salicylate, plumbagin, 2,4-dinitrophe- } \\
\text { nol, menadione }\end{array}$ & $0.5-1 \mathrm{mM}$ & $\begin{array}{l}\text { Cohen et al., } \\
1993 b \\
\text { Seoane and Levy, } \\
1995 \\
\text { Martin and Rosner, } \\
1995 \\
\text { Alekshun and } \\
\text { Levy, 1999a } \\
\text { Alekshun et al., } \\
2001\end{array}$ \\
\hline OhrR & $\begin{array}{l}\text { Xanthomonas campestris and } \\
\text { Bacillus subtilis }\end{array}$ & $\begin{array}{l}\text { tert-butyl hydroperoxide, cumene } \\
\text { hydroperoxide }\end{array}$ & -- & $\begin{array}{l}\text { Sukchawalit et al., } \\
2001 \\
\text { Panmanee et al., } \\
2002 \\
\text { Fuangthong et al., } \\
2001 \\
\text { Fuangthong and } \\
\text { Helmann, } 2002\end{array}$ \\
\hline HucR & Deinococcus radiodurans & uric acid, salicylate & $11.6 \mu \mathrm{M}$ & $\begin{array}{l}\text { Wilkinson and } \\
\text { Grove, } 2004 \\
\text { Wilkinson and } \\
\text { Grove, } 2005\end{array}$ \\
\hline
\end{tabular}

absence of any potential effectors (Lim et al., 2002). However, the C-terminal polypeptide from an adjacent dimer was inserted in the cleft between the DNA-binding domains of MexR dimer "AB", resulting in a dimer significantly different in conformation than the dimer $C D$ that was modeled onto the MexR DNA-binding site (see below). The polypeptide was stabilized between the DNAbinding lobes by electrostatic interactions between the positively charged residues of the dimer lining the crevice and negatively charged glutamate and aspartate residues from the inserted polypeptide. Several van der Waals contacts between proline, leucine and isoleucine residues in the polypeptide with hydrophobic residues lining the crevice of the dimer also stabilized the interaction.

\section{Proposed mechanisms of allosteric regulation of MarR proteins}

As discussed above, MarR in its salicylate-bound conformation is unlikely to bind its sequence specific DNAbinding site (Alekshun et al., 2001). The location of the two salicylate binding sites on either side of the proposed DNA recognition helix suggests possible mechanisms by which phenolic ligands antagonize MarR-DNA interaction. As both ligand-binding sites SAL-A and SAL-B are composed of residues from the DNA-recognition helix and wing motif, and as both of these regions of the winged helix fold have been shown to be critical for DNA-binding, it is clear that the ligand- and DNA-binding sites are not separate. Moreover, this overlap of domains is conserved throughout the family (Fig. 1). It is plausible that ligand binding at one or both sites coordinates residues required for direct or water-mediated contacts with the cognate DNA-binding site, thus preventing complex formation (Alekshun et al., 2000). Alternatively, or in combination with the effect posited above, ligand binding might stabilize a MarR dimer conformation that cannot accommodate the insertion of the recognition helices into the major grooves at the binding sequence half-sites. The suggested intrinsic flexibility of MarR at the dimerization interface is consistent with a ligand-mediated conformational shift in the relative positions of the DNA-binding lobes, from a DNA-binding state to the state observed in the crystal structure.

The four dimers present in the crystallographic asymmetric unit of MexR provided a fortuitous glimpse of a possible mechanism of ligand-mediated allosteric control of MexR-DNA binding (Lim et al., 2002). A comparison of the "open" MexR dimer CD conformation (Fig. 2b), that was readily modeled onto its linear B-form DNA binding site, with the MexR dimer AB-polypeptide conformation, revealed the latter to be incompatible with binding to its 
recognition sequence. Notably, the distance separating the centers of the recognition helices is reduced to $22.6 \AA$ in the MexR dimer $A B$, compared to the distance of 29.2 $\AA$ observed in the "open" conformation. Comparisons of all four dimer representations revealed that the basis for this conformational shift resided in the intrinsic flexibility of the dimerization domain. Whereas the winged helix DNAbinding domains appeared to move as a rigid body, flexible loop regions allow for significant conformational flexibility in $\alpha$-helices 1,5 and 6 . The helix orientations of $\alpha$-helices 1,5 and 6 vary by $17^{\circ}, 6.8^{\circ}$, and $12.1^{\circ}$, respectively, with their midpoint positions deviating by $4.9 \AA, 1.7 \AA$, and $8.2 \AA$. This flexibility of the helices that comprise the dimerization domain is consistent with variable geometries allowed for the van der Waals contacts that stabilize the dimer. As $\alpha$-helices 1 and 5 connect the dimerization domain to the DNA-binding domain, their flexibility results in concomitant shifts in the DNA-binding lobes. The "closed" conformation observed for MexR dimer AB suggests that ligands may disrupt MexR-DNA complex formation by neutralizing the electrostatic repulsion that otherwise maintain the dimer in an "open" DNA-binding conformation. Additional hydrophobic contacts between the ligand and residues lining the crevice of the MexR dimer contribute to bring the DNA-binding lobes into closer proximity. As all known ligands of MarR homologs are anionic lipophilic compounds, it is tempting to speculate that members of this family share a similar mechanism of allosteric control.

\section{The physiological relevance of two ligand-binding sites}

The physiological relevance of the two ligand-binding sites per monomer seen in the MarR structure was unclear, as the crystals were soaked in a very high concentration of salicylate. Fits of equilibrium dialysis data for EmrR suggested a single ligand-binding site per monomer (Brooun et al., 1999). Also, despite the significant conservation of residues comprising site SAL-A, MexR does not respond to salicylate as an effector in vitro, while HucR exhibits much tighter binding to its natural ligand urate compared to salicylate. These observations suggest an unusual conformational flexibility in this ligand-binding site to accommodate distinct ligands. Indeed, the ability to respond to a multitude of structurally distinct effector molecules is a unique feature of this protein family.

Analysis of uric acid binding to HucR revealed negative cooperativity, inferred to involve the SAL-B sites in each monomer (Wilkinson and Grove, 2005). Notably, this negative cooperativity is abolished upon mutation of conserved residues in SAL-A, suggesting that occupancy of the SAL-A site may be required for manifestation of this regulatory mechanism. Taken together, the conservation of residues comprising the SAL-A site (Fig. 1) and the biochemical data from HucR support a physiological role of ligand binding at the SAL-A site, perhaps in fine-tuning the response of the respective transcriptional regulator to ligands bound at the SAL-B site. Moreover, the presence of multiple ligand binding sites per protomer is consistent with the existence of diverse effector compounds (Table 2 ), and the lack of sequence conservation of the SAL-B site corroborates the variety of ligand specificities seen in this family.

The OhrR proteins from $X$. campestris pv. phaseoli and $B$. subtilis employ an alternative allosteric mechanism of ligand-induced conformational changes (Panmanee et al., 2002; Fuangthong et al., 2002). In each of these proteins, organic hydroperoxides antagonize DNA-binding by oxidizing a conserved cysteine in the $\mathrm{N}$-terminal region. As this cysteine does not mediate contacts with DNA, ligand-induced oxidation of the cysteine to a cysteinesulfenic acid likely causes a conformational change in the dimerization domain of OhrR that propagates to the DNA-recognition domain, resulting in an orientation of the winged helix lobes of the dimer that is incompatible with DNA binding.

The DNA- and ligand-binding data for MarR proteins in toto is consistent with a unique mechanism of effectormediated DNA-binding involving overlapping DNA- and ligand-binding domains (with the possible exception of $\mathrm{OhrR}$ ). This family includes the only prokaryotic transcriptional regulators to employ such an allosteric mechanism of multidrug recognition. The transitions between DNA- and ligand-bound states are likely dependent upon the intrinsic conformational flexibility of MarR proteins and their capacity to alter DNA helical twist at their cognate sequences. The model suggests that ligand-binding at high-affinity sites effects a global conformational change that alters the relative orientations of the DNA-binding lobes of the dimer, altering the DNAbinding capacity of the protein. We suggest that occupancy of the SAL-A site may induce negative cooperativity of ligand-binding to the SAL-B site, thus enhancing the sensitivity of MarR homologs to low concentrations of effector molecules and increasing their capacity for transcriptional regulation.

\section{Acknowledgment}

Support of our research from The National Science Foundation (MCB-0414875 to A.G.) is gratefully acknowledged.

\section{References}

Alekshun, M.N. and Levy, S.B. (1999a) Alteration of the repressor activity of MarR, the negative regulator of the Escherichia coli marRAB locus, by multiple chemicals in vitro. J. Bacteriol. 181, 4669-4672.

Alekshun, M.N. and Levy, S.B. (1999b) Characterization of MarR superrepressor mutants. J. Bacteriol. 181, 3303-3306.

Alekshun, M.N., Kim, Y.S., and Levy, S.B. (2000) Mutational analysis of MarR, the negative regulator of marRAB expression in Escherichia coli, suggests the presence of two regions required for DNA binding. Mol. Microbiol. 35, 1394-1404.

Alekshun M.N., Levy S.B., Mealy T.R., Seaton B.A., and Head J.F. (2001) The crystal structure of MarR, a regulator of multiple antibiotic resistance, at $2.3 \AA$ resolution. Nature Struct. Biol. 8, 710-714.

Aravind, L., and Koonin, E.V. (1999) DNA-binding proteins and evolution of transcription regulation in the archaea. Nucleic Acids Res. 27, 4658-4670. 
Ariza, R.R., Cohen, S.P., Bachhawat, N., Levy, S.B., and Demple, B. (1994) Repressor mutations in the marRAB operon that activate oxidative stress genes and multiple antibiotic resistance in Escherichia coli. J. Bacteriol. 176, 143-148.

Asako, H., Nakajima, H., Kobayashi, K., Kobayashi, M., and Aono, R. (1997) Organic solvent tolerance and antibiotic resistance increased by overexpression of marA in Escherichia coli. Appl. Environ. Microbiol. 63, 1428-1433.

Bartels, F.W., Baumgarth, B., Anselmetti, D., Ros, R., and Becker, A. (2003) Specific binding of the regulatory protein ExpG to promoter regions of the galactoglucan biosynthesis gene cluster of Sinorhizobium meliloti--a combined molecular biology and force spectroscopy investigation. J. Struct. Biol. 143, 145-152.

Baumgarth B., Bartels, F.W., Anselmetti, D., Becker, A., and Ros, R. (2005) Detailed studies of the binding mechanism of the Sinorhizobium meliloti transcriptional activator ExpG to DNA. Microbiology 151, 259-268.

Becker, A., Rüberg, S., Küster, H., Roxlau, A.A., Keller, M., Ivashina, T., Cheng, H.P., Walker, G.C., and Pühler, A. (1997) The 32-kilobase exp gene cluster of Rhizobium meliloti directing the biosynthesis of galactoglucan: genetic organization and properties of the encoded gene products. J. Bacteriol. 179, 1375-1384.

Brennan, R.G. (1993) The winged-helix DNA-binding motif: another helix-turn-helix takeoff. Cell 74, 773776.

Brooun, A., Tomashek, J.J., and Lewis, K. (1999) Purification and ligand binding of EmrR, a regulator of a multidrug transporter. J. Bacteriol. 181, 5131-5133.

Chollet, R., Bollet, C., Chevalier, J., Malléa, M., Pagès, J-M., and Davin-Regli, A. (2002) mar Operon involved in multidrug resistance of Enterobacter aerogenes. Antimicrob. Agents Chemother. 46, 1093-1097.

Clark, K.L., Halay, E.D., Lai, E., and Burley, S.K. (1993) Co-crystal structure of the HNF-3/fork head DNArecognition motif resembles histone $\mathrm{H} 5$. Nature 364 , 412-420.

Cohen, S.P., McMurry, L.M., Hooper, D.C., Wolfson, J.S., and Levy, S.B. (1989) Cross-resistance to fluoroquinolones in multiple-antibiotic-resistant (Mar) Escherichia coli selected by tetracycline or chloramphenicol: decreased drug accumulation associated with membrane changes in addition to OmpF reduction. Antimicrob. Agents Chemother. 33, 1318-1325.

Cohen, S.P., Hächler, H., and Levy, S.B. (1993a) Genetic and functional analysis of the multiple antibiotic resistance (mar) locus in Escherichia coli. J. Bacteriol. 175, 1484-1492.

Cohen, S.P., Levy, S.B., Foulds, J., and Rosner, J.L. (1993b) Salicylate induction of antibiotic resistance in Escherichia coli: activation of the maroperon and a marindependent pathway. J. Bacteriol. 175, 7856-7862.

Cohen, S.P., McMurry, L.M., and Levy, S.B. (1988) marA locus causes decreased expression of OmpF porin in multiple-antibiotic-resistant (Mar) mutants of Escherichia coli. J. Bacteriol. 170, 5416-5422.

del Castillo, I., Gomez, J.M., and Moreno, F. (1990) mprA, an Escherichia coli gene that reduces growth-phase- dependent synthesis of microcins B17 and C7 and blocks osmoinduction of proU when cloned on a highcopy-number plasmid. J. Bacteriol. 172, 437-445.

Dalrymple, B.P. and Swadling, Y. (1997) Expression of a Butyrivibrio fibrisolvens E14 gene ( $\operatorname{cin} B$ ) encoding an enzyme with cinnamoyl ester hydrolase activity is negatively regulated by the product of an adjacent gene (cinR) Microbiology 143, 1203-1210.

Egland, P.G. and Harwood, C.S. (1999) BadR, a new MarR family member, regulates anaerobic benzoate degradation by Rhodopseudomonas palustris in concert with AadR, an Fnr family member. J. Bacteriol. 181, 2102-2109.

Evans, K., Adewoye, L., and Poole, K. (2001) MexR repressor of the mexAB-oprM multidrug efflux operon of Pseudomonas aeruginosa: identification of MexR binding sites in the mexA-mexR intergenic region. J. Bacteriol. 183, 807-812.

Fuangthong, M., Atichartpongkul, S., Mongkolsuk, S., and Helmann, J.D. (2001) OhrR is a repressor of ohrA, a key organic hydroperoxide resistance determinant in Bacillus subtilis. J. Bacteriol. 183, 4134-4141.

Fuangthong, M. and Helmann, J.D. (2002) The OhrR repressor senses organic hydroperoxides by reversible formation of a cysteine-sulfenic acid derivative. Proc. Natl. Acad. Sci. USA. 99, 6690-6695.

Gajiwala, K.S. and Burley, S.K. (2000) Winged helix proteins. Curr. Opin. Struct. Biol. 10, 110-116.

Gajiwala, K.S., Chen, H., Cornille, F., Roques, B.P., Reith, W., Mach, B., and Burley, S.K. (2000) Structure of the winged-helix protein hRFX1 reveals a new mode of DNA binding. Nature 403, 916-921.

Galán, B., Kolb, A., Sanz, J.M., García, J.L., and Prieto, M.A. (2003) Molecular determinants of the hpa regulatory system of Escherichia coli: the HpaR repressor. Nucleic Acids Res. 31, 6598-6609.

Gambino, L., Gracheck, S.J., and Miller, P.F. (1993) Overexpression of the MarA positive regulator is sufficient to confer multiple antibiotic resistance in Escherichia coli. J. Bacteriol. 175, 2888-2894.

George, A.M. and Levy, S.B. (1983a) Amplifiable resistance to tetracycline, chloramphenicol, and other antibiotics in Escherichia coli: involvement of a nonplasmid-determined efflux of tetracycline. J. Bacteriol. 155, 531-540.

George, A.M. and Levy, S.B. (1983b) Gene in the major cotransduction gap of the Escherichia coli K-12 linkage map required for the expression of chromosomal resistance to tetracycline and other antibiotics. J. Bacteriol. 155, 541-548.

Jair, K.-W., Martin, R.G., Rosner, J.L., Fujita, N., Ishihama, A., and Wolf, R.E., Jr. (1995) Purification and regulatory properties of MarA protein, a transcriptional activator of Escherichia coli multiple antibiotic and superoxide resistance promoters. J. Bacteriol. 177, 7100-7104.

Jin, C. and Liao, X. (1999) Backbone dynamics of a winged helix protein and its DNA complex at different temperatures: changes of internal motions in genesis upon binding to DNA. J. Mol. Biol. 292, 641-651.

Jin, C., Marsden, I., Chen, X., and Liao, X. (1999) Dynamic DNA contacts observed in the NMR structure of winged helix protein-DNA complex. J. Mol. Biol. 289, 683-90. 
Lee, E.-H., Rouquette-Loughlin, C., Folster, J.P., and Shafer, W.M. (2003) FarR regulates the farAB-encoded efflux pump of Neisseria gonorrhoeae via an MtrR regulatory mechanism. J. Bacteriol. 185, 7145-7152.

Lim, D., Poole, K., and Strynadka, N.C.J. (2002) Cyrstal structure of the MexR repressor of the mexRAB-oprM multidrug efflux operon of Pseudomonas aeruginosa. J. Biol. Chem. 277, 29253-29259.

Lomovskaya, O., Lewis, K., and Matin, A. (1995) EmrR is a negative regulator of the Escherichia coli multidrug resistance pump EmrAB. J. Bacteriol. 177, 23282334.

Maneewannakul, K. and Levy, S.B. (1996) Identification for mar mutants among quinolone-resistant clinical isolates of Escherichia coli. Antimicrob. Agents Chemother. 40, 1695-1698.

Marsden, I., Jin, C., and Liao, X. (1998) Structural changes in the region directly adjacent to the DNA-binding helix highlight a possible mechanism to explain the observed changes in the sequence-specific binding of winged helix proteins. J. Mol. Biol. 278, 293-299.

Martin, R.G., Jair, K.-W., Wolf, R.E., Jr., and Rosner, J.L. (1996) Autoactivation of the marRAB multiple antibiotic resistance operon by the MarA transcriptional activator in Escherichia coli. J. Bacteriol. 178, 2216-2223.

Martin, R.G. and Rosner, J.L. (1995) Binding of purified multiple antibiotic-resistance repressor protein (MarR) to mar operator sequences. Proc. Natl. Acad. Sci. USA. 92, 5456-5460.

Martínez-Hackert, E. and Stock, A.M. (1997) The DNAbinding domain of OmpR: crystal structures of a winged helix transcription factor. Structure 5, 109-124.

Mongkolsuk, S., Panmanee, W., Atichartpongkul, S., Vattanaviboon, P., Whangsuk, W., Fuangthong, M., Eiamphungporn, W., Sukchawalit, R., and Utamapongchai, S. (2002) The repressor for an organic peroxide-inducible operon is uniquely regulated at multiple levels. Mol. Microbiol. 44, 793-802.

Okusu, H., Ma, D., and Nikaido, H. (1996) AcrAB efflux pump plays a major role in the antibiotic resistance phenotype of Escherichia coli multiple-antibioticresistance (Mar) mutants. J. Bacteriol. 178, 306-308.

Ouhammouch, M., and Geiduschek, E.P. (2001) A thermostable platform for transcriptional regulation: the DNA-binding properties of two Lrp homologs from the hyperthermophilic archaeon Methanococcus jannaschii. EMBO J. 20, 146-156.

Panmanee, W., Vattanaviboon, P., Eiamphungporn, W., Whangsuk, W., Sallabhan, R., and Mongkolsuk, S. (2002) OhrR, a transcription repressor that senses and responds to changes in organic peroxide levels in Xanthomonas campestris pv. phaseoli. Mol. Microbiol. 45, 1647-1654.

Parke, D. and Ornston, L.N. (2003) Hydroxycinnamate (hca) catabolic genes from Acinetobacter sp. strain ADP1 are repressed by $\mathrm{HcaR}$ and are induced by hydroxycinnamoyl-coenzyme A thioesters. Appl. Environ. Microbiol. 69, 5398-5409.

Pérez-Rueda, E. and Collado-Vides, J. (2001) Common history at the origin of the position-function correlation in transcriptional regulators in archaea and bacteria. J. Mol. Evol. 53, 172-179.
Pérez-Rueda, E., Collado-Vides, J., and Segovia, L. (2004) Phylogenetic distribution of DNA-binding transcription factors in bacteria and archaea. Comput. Biol. Chem. 28, 341-350.

Poole, K., Tetro, K., Zhao, Q., Neshat, S., Heinrichs, D.E., and Bianco, N. (1996) Expression of the multidrug resistance operon mexA-mexB-oprM in Pseudomonas aeruginosa: mexR encodes a regulator of operon expression. Antimicrob. Agents Chemother. 40, 20212028.

Praillet, T., Nasser, W., Robert-Baudouy, J., and Reverchon, S. (1996) Purification and functional characterization of PecS, a regulator of virulence-factor synthesis in Erwinia chrysanthemi. Mol. Microbiol. 20, 391-402.

Praillet, T., Reverchon, S., and Nasser, W. (1997) Mutual control of the PecS/PecM couple, two proteins regulating virulence-factor synthesis in Erwinia chrysanthemi. Mol. Microbiol. 24, 803-814.

Providenti, M.A. and Wyndham, R.C. (2001) Identification and functional characterization of CbaR, a MarR-like modulator of the cbaABC-encoded chlorobenzoate catabolism pathway. Appl. Environ. Microbiol. 67, 3530-3541.

Raman, N., Black, P.N., and DiRusso, C.C. (1997) Characterization of the fatty acid-responsive transcription factor FadR. Biochemical and genetic analyzes of the native conformation and functional domains. J. Biol. Chem. 272, 30645-30650.

Reverchon, S., Rouanet, C., Expert, D., and Nasser, W. (2002) Characterization of indigoidine biosynthetic genes in Erwinia chrysanthemi and role of this blue pigment in pathogenicity. J. Bacteriol. 184, 654-665.

Rhee, S., Martin, R.G., Rosner, J.L., and Davies, D.R. (1998) A novel DNA-binding motif in MarA: the first structure for an AraC family transcriptional activator. Proc. Natl. Acad. Sci. USA. 95, 10413-10418.

Rouanet, C., Nomura, K., Tsuyumu, S., and Nasser, W. (1999) Regulation of pelD and pelE, encoding major alkaline pectate lyases in Erwinia chrysanthemi: involvement of the main transcriptional factors. J. Bacteriol. 181, 5948-5957.

Rouanet, C., Reverchon, S., Rodionov, D.A., and Nasser, W. (2004) Definition of a consensus DNA-binding site for PecS, a global regulator of virulence gene expression in Erwinia chrysanthemi and identification of new members of the PecS regulon. J. Biol. Chem. 279, 30158-30167.

Rüberg, S., Pühler, A., and Becker, A. (1999) Biosynthesis of the exopolysaccharide galactoglucan in Sinorhizobium meliloti is subject to a complex control by the phosphate-dependent regulator $\mathrm{PhoB}$ and the proteins ExpG and MucR. Microbiology 145, 603-611.

Seoane, A.S. and Levy, S.B. (1995) Characterization of MarR, the repressor of the multiple antibiotic resistance (mar) operon in Escherichia coli. J. Bacteriol. 177, 3414-3419.

Shi, Y., Latifi, T., Cromie, M.J., and Groisman, E.A. (2004) Transcriptional control of the antimicrobial peptide resistance ugtL gene by the Salmonella PhoP and SlyA regulatory proteins. J. Biol. Chem. 279, 38618-38625. 
Spory, A., Bosserhoff, A., von Rhein, C., Goebel, W., and Ludwig, A. (2002) Differential regulation of multiple proteins of Escherichia coli and Salmonella enterica serovar Typhimurium by the transcriptional regulator SlyA. J. Bacteriol. 184, 3549-3459.

Srikumar, R., Paul, C.J., and Poole, K. (2000) Influence of mutations in the mex $R$ repressor gene on expression of the MexA-MexB-oprM multidrug efflux system of Pseudomonas aeruginosa. J. Bacteriol. 182, 14101414.

Stapleton, M.R., Norte, V.A., Read, R.C., and Green, J. (2002) Interaction of the Salmonella typhimurium transcription and virulence factor SlyA with target DNA and identification of members of the SlyA regulon. J. Biol. Chem. 277, 17630-17637.

Sukchawalit, R., Loprasert, S., Atichartpongkul, S., and Mongkolsuk, S. (2001) Complex regulation of the organic hydroperoxide resistance gene (ohr) from Xanthomonas involves OhrR, a novel organic peroxideinducible negative regulator, and posttranscriptional modifications. J. Bacteriol. 183, 4405-4412.

Sulavik, M.C., Dazer, M., and Miller, P.F. (1997) The Salmonella typhimurium mar locus: molecular and genetic analyzes and assessment of its role in virulence. J. Bacteriol. 179, 1857-1866.

Sulavik, M.C., Gambino, L.F., and Miller, P.F. (1994) Analysis of the genetic requirements for inducible multiple-antibiotic resistance associated with the mar locus in Escherichia coli. J. Bacteriol. 176, 7754-7756.

van Aalten, D.M., DiRusso, C.C., and Knudsen, J. (2001) The structural basis of acyl coenzyme A-dependent regulation of the transcription factor FadR. EMBO J. 20, 2041-2050.

Wilkinson, S.P. and Grove, A. (2004) HucR, a novel uric acid-responsive member of the MarR family of transcriptional regulators from Deinococcus radiodurans. J. Biol. Chem. 279, 51442-51450.

Wilkinson, S.P. and Grove, A. (2005) Negative Cooperativity of Uric Acid Binding to the Transcriptional Regulator HucR from Deinococcus radiodurans. J. Mol. Biol. 350, 617-630.

Wilson, K.P., Shewchuk, L.M., Brennan, R.G., Otsuka, A.J., and Matthews, B.W. (1992) Escherichia coli biotin holoenzyme synthetase/bio repressor crystal structure delineates the biotin- and DNA-binding domains. Proc. Natl. Acad. Sci. USA. 89, 9257-9261.

Wojciak, J.M., Iwahara, J., and Clubb, R.T. (2001) The Mu repressor-DNA complex contains an immobilized 'wing' within the minor groove. Nature Struct. Biol. 8, 84-90.

Wyborn, N.R., Stapleton, M.R., Norte, V.A., Roberts, R.E., Grafton, J., and Green, J. (2004) Regulation of Escherichia coli hemolysin E expression by $\mathrm{H}-\mathrm{NS}$ and Salmonella SlyA. J. Bacteriol. 186, 1620-1628.

Wu, R., Zhang, R., Zagnitko, O., Dementieva, I., Maltzev, N., Watson, J.D., Laskowski, R., Gornicki, P., and Joachimiak, A. (2003) Crystal structure of Enterococcus fecalis SlyA-like transcriptional factor. J. Biol. Chem. 278, 20240-20244.

Xiong, A., Gottman, A., Park, C., Baetens, M., Pandza, S., and Matin, A. (2000) The EmrR protein represses the Escherichia coli emrRAB multidrug resistance operon by directly binding to its promoter region. Antimicrob. Agents Chemother. 44, 2905-2907.

Zheleznova Heldwein, E.E. and Brennan, R.G. (2001) Crystal structure of the transcription activator BmrR bound to DNA and a drug. Nature 409, 378-382.

Zheng, N., Fraenkel, E., Pabo, C.O., and Pavletich, N.P. (1999) Structural basis of DNA recognition by the heterodimeric cell cycle transcription factor E2F-DP. Genes Dev. 13, 666-674. 


\section{Further Reading}

Caister Academic Press is a leading academic publisher of advanced texts in microbiology, molecular biology and medical research. Full details of all our publications at caister.com

- MALDI-TOF Mass Spectrometry in Microbiology Edited by: M Kostrzewa, S Schubert (2016) www.caister.com/malditof

- Aspergillus and Penicillium in the Post-genomic Era Edited by: RP Vries, IB Gelber, MR Andersen (2016) www.caister.com/aspergillus2

- The Bacteriocins: Current Knowledge and Future Prospects Edited by: RL Dorit, SM Roy, MA Riley (2016)

www.caister.com/bacteriocins

- Omics in Plant Disease Resistance Edited by: V Bhadauria (2016) www.caister.com/opd

- Acidophiles: Life in Extremely Acidic Environments Edited by: R Quatrini, DB Johnson (2016) www.caister.com/acidophiles

- Climate Change and Microbial Ecology: Current Research and Future Trend

Edited by: J Marxsen (2016)

www.caister.com/climate

- Biofilms in Bioremediation: Current Research and Emerging Technologies

Edited by: G Lear (2016)

www.caister.com/biorem

- Microalgae: Current Research and Applications Edited by: MN Tsaloglou (2016) www.caister.com/microalgae

- Gas Plasma Sterilization in Microbiology: Theory, Applications, Pitfalls and New Perspectives Edited by: H Shintani, A Sakudo (2016) www.caister.com/gasplasma

- Virus Evolution: Current Research and Future Directions Edited by: SC Weaver, M Denison, M Roossinck, et al. (2016) www.caister.com/virusevol

- Arboviruses: Molecular Biology, Evolution and Control Edited by: N Vasilakis, DJ Gubler (2016) www.caister.com/arbo

- Shigella: Molecular and Cellular Biology Edited by: WD Picking, WL Picking (2016) www.caister.com/shigella

-Aquatic Biofilms: Ecology, Water Quality and Wastewater Treatment

Edited by: AM Romaní, H Guasch, MD Balaguer (2016)

www.caister.com/aquaticbiofilms

- Alphaviruses: Current Biology

Edited by: S Mahalingam, L Herrero, B Herring (2016)

www.caister.com/alpha

- Thermophilic Microorganisms

Edited by: F Li (2015)

www.caister.com/thermophile
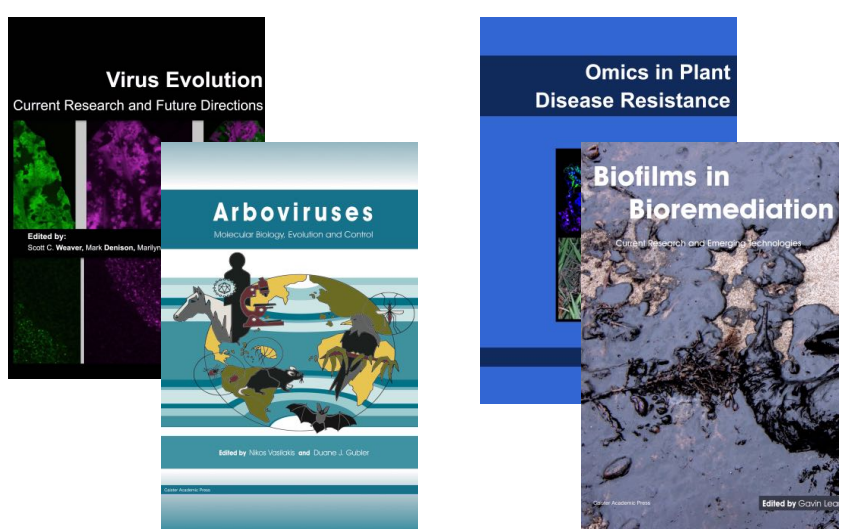
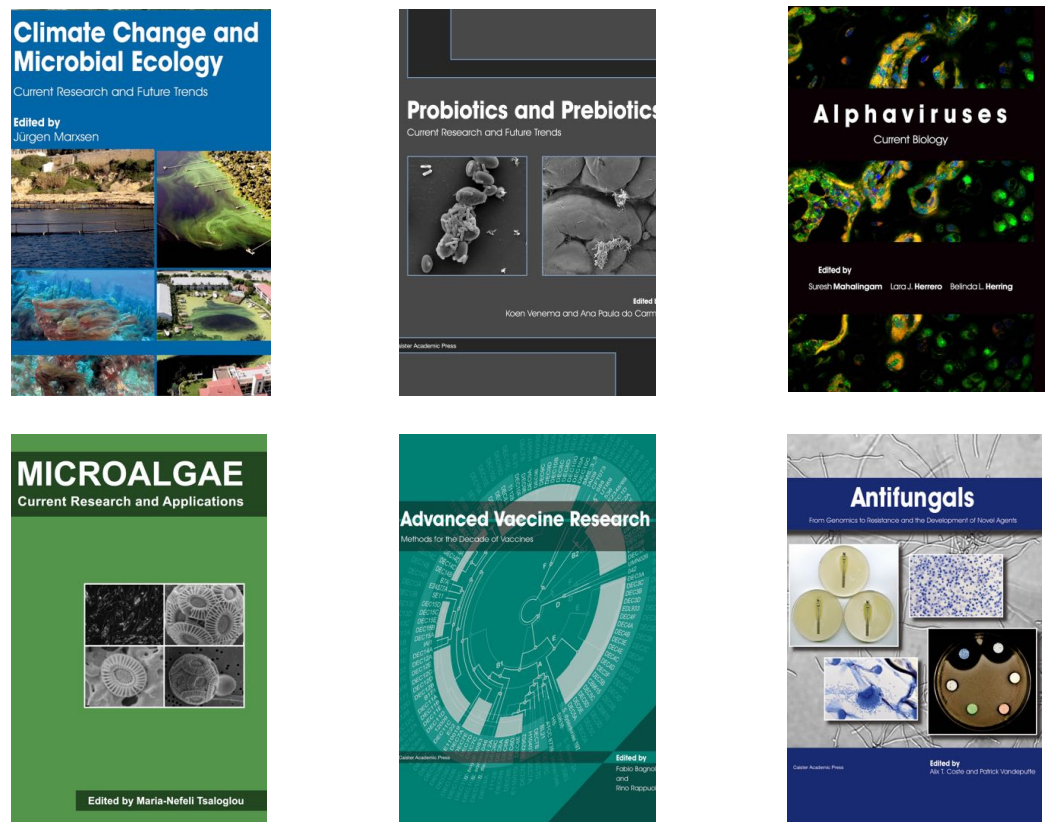

- Flow Cytometry in Microbiology: Technology and Applications Edited by: MG Wilkinson (2015) www.caister.com/flow

- Probiotics and Prebiotics: Current Research and Future Trends Edited by: K Venema, AP Carmo (2015) www.caister.com/probiotics

- Epigenetics: Current Research and Emerging Trends Edited by: BP Chadwick (2015) www.caister.com/epigenetics2015

- Corynebacterium glutamicum: From Systems Biology to Biotechnological Applications

Edited by: A Burkovski (2015)

www.caister.com/cory2

- Advanced Vaccine Research Methods for the Decade of Vaccines

Edited by: F Bagnoli, R Rappuoli (2015)

www.caister.com/vaccines

- Antifungals: From Genomics to Resistance and the Development of Novel Agents

Edited by: AT Coste, P Vandeputte (2015)

www.caister.com/antifungals

- Bacteria-Plant Interactions: Advanced Research and Future Trends Edited by: J Murillo, BA Vinatzer, RW Jackson, et al. (2015) www.caister.com/bacteria-plant

\section{- Aeromonas}

Edited by: J Graf (2015)

www.caister.com/aeromonas

- Antibiotics: Current Innovations and Future Trends

Edited by: S Sánchez, AL Demain (2015)

www.caister.com/antibiotics

- Leishmania: Current Biology and Contro Edited by: S Adak, R Datta (2015) www.caister.com/leish2

- Acanthamoeba: Biology and Pathogenesis (2nd edition) Author: NA Khan (2015)

www.caister.com/acanthamoeba2

- Microarrays: Current Technology, Innovations and Applications Edited by: Z He (2014)

www.caister.com/microarrays2

- Metagenomics of the Microbial Nitrogen Cycle: Theory, Methods and Applications

Edited by: D Marco (2014)

www.caister.com/n2 